\title{
Review
}

\section{Effects of environmental change on wildlife health}

\author{
Karina Acevedo-Whitehouse ${ }^{1, *}$ and Amanda L. J. Duffus ${ }^{1,2}$ \\ ${ }^{1}$ Institute of Zoology, Zoological Society of London, Regent's Park, London NW1 4RY, UK \\ ${ }^{2}$ School of Biological and Chemical Sciences, Queen Mary, University of London, London E1 4NS, UK
}

Environmental change has negatively affected most biological systems on our planet and is becoming of increasing concern for the well-being and survival of many species. At an organism level, effects encompass not only endocrine disruptions, sex-ratio changes and decreased reproductive parameters, but also include teratogenic and genotoxic effects, immunosuppression and other immune-system impairments that can lead directly to disease or increase the risk of acquiring disease. Living organisms will strive to maintain health by recognizing and resolving abnormal situations, such as the presence of invading microorganisms or harmful peptides, abnormal cell replication and deleterious mutations. However, fast-paced environmental changes may pose additional pressure on immunocompetence and health maintenance, which may seriously impact population viability and persistence. Here, we outline the importance of a functional immune system for survival and examine the effects that exposure to a rapidly changing environment might exert on immunocompetence. We then address the various levels at which anthropogenic environmental change might affect wildlife health and identify potential deficits in reproductive parameters that might arise owing to new immune challenges in the context of a rapidly changing environment. Throughout the paper, a series of examples and case studies are used to illustrate the impact of environmental change on wildlife health.

Keywords: anthropogenic stressors; environmental change; health; immunocompetence; survival; wildlife

\section{INTRODUCTION}

Our planet is currently suffering a staggering rate of dramatic environmental change. Around the world, ecosystems are increasingly subjected to the negative effects of human population growth and its expanding ecological footprint (Jackson et al. 2001; Hughes et al. 2003). Be it in the form of habitat loss or alteration, the introduction of invasive species, pathogen spillover, accumulation of persistent pollutants, climate change or stratospheric ozone depletion, global environmental change has altered physical and biological systems and is becoming of increasing concern for the well-being and survival of many species (Thomas et al. 2004; Hoffmann \& Willi 2008).

Predicting the consequences of global environmental change on biodiversity is a complex task mainly because the effects encompass multiple and complex dynamic processes that rarely have single and clear-cut actions. Rather, the effects appear to interact and can even have additive costs, and these can manifest at several levels. For instance, habitat degradation and fragmentation not only may decrease food availability and restrict the movement of animals,

* Author for correspondence (karina.acevedo-whitehouse@ioz.ac.uk).

One contribution of 11 to a Theme Issue 'Impacts of environmental change on reproduction and development in wildlife'. thus impairing nutritional status and limiting gene flow, but also may increase the opportunity for contact among humans, domestic livestock and wildlife (Deem et al. 2001), potentially enhancing disease transmission rates (Smith et al. 2009). Furthermore, pollutants can alter habitat quality, reduce nutrient availability and encourage toxic algae blooms along coastlines (Smith 2003; Havens 2008; Paul 2008), all of which can indirectly affect the survival of sensitive species; furthermore, pollutants can directly impact reproductive parameters (Sonne et al. 2006, 2007), sex ratios (Reusch \& Wood 2007) and immunocompetence (Selgrade 2007). Because of this very complexity, environmental change is likely to seriously impair the viability of wildlife.

It could be argued that living organisms have long been subject to a myriad of evolutionary pressures arising from the environment (Reusch \& Wood 2007) and are consequently well adapted to respond to such pressures. However, the current pace of environmental change is unprecedented (Thomas et al. 2004) and it is unknown whether the capacity of species to adapt to such changes and counteract their harmful and often combined effects may be exceeded. Regrettably, published data on this subject are still extremely limited, making it difficult to understand the full extent of the effects of environmental change on wildlife health. 
In the hope that this paper will stimulate the research much needed for assessing wildlife health in the context of a rapidly changing environment, we (i) review the key role of an optimally functional immune system for survival, (ii) examine the effects that exposure to fast-paced change might exert on immunocompetence, (iii) discuss the direct consequences that various drivers of environmental change can exert on health and (iv) identify some of the levels at which these effects might impinge on reproductive parameters. We conclude the paper by proposing avenues of research that we consider to be necessary for a more complete understanding of the effects of environmental change on wildlife health.

\section{THE IMMUNE SYSTEM AND ITS ROLE IN SURVIVAL}

All organisms are constantly exposed to a wide and changing array of pathogens, foreign peptides, abnormal cell replication and occurrence of deleterious mutations. Under normal circumstances, organisms will strive to maintain health by recognizing and resolving abnormal situations. Responses comprise a complex and interactive network of specific and nonspecific humoral and cell-mediated components, broadly defined as immune responses (Tizard 2002), which will largely depend upon opportune recognition of the antigen, the presence and structure of antigen cell membrane receptors, the intensity of exposure to the antigen, a timely activation of containment and destruction measures and, ultimately, the generation of a specific and definitive adaptive immune response (Nizet 2006). The optimal functioning of these responses is known collectively as immunocompetence.

Presenting a detailed description of the components and mechanisms of action of the immune system is well beyond the scope of this paper, and there exist several excellent up-to-date reviews on the immune system of vertebrates (e.g. Borghesi \& Milcarek 2007; Kvell et al. 2007) which can be consulted to obtain a better understanding of the immune repertoire and its mechanisms of action. What is of relevance here is to underscore the importance of immunocompetence for survival (Lochmiller 1996). This crucial role has been demonstrated by clinical and experimental studies of humans and laboratory animals that show that immune-deficient or -suppressed organisms tend to have defective wound healing (Uba et al. 2004), higher mortality rates, shorter lifespans and develop more severe infectious diseases and cancer (Brandau \& Gilbert 2007; Norlin et al. 2008).

While there are few studies of the relative importance of different immune effectors in terms of wildlife survival, most likely owing to the difficulty of controlling for all confounding factors (including variation in exposure to pathogens and nutritional differences), research on a number of bird species has demonstrated that even simple estimates of nonspecific immune responses can reliably predict a large and significant amount of variation in survivorship (e.g. Moller \& Saino 2004; Haussmann et al. 2005), even when accounting for differences in body condition (Hanssen et al. 2003).

\section{ENVIRONMENTAL STRESS AND IMMUNE COMPETENCE}

In order to function adequately, the immune system is dependent on numerous regulatory interactions between organs, in a complex set of hormone and neuropeptide connections involving the nervous and endocrine systems. When an organism is faced with a stressor-broadly defined as 'any aversive condition, be it a predator or an aggressive conspecific, disturbance to established social hierarchies, overcrowding, an infective parasite or foreign peptide or thermal extremes' (Husband \& Bryden 1996) that would affect fitness if not avoided or successfully tolerated (Martin 2009)—various body systems act together to activate and coordinate responses. This cascade of events involves synergistic, agonistic or antagonistic interactions between the sympathetic adrenomedullary system, the hypothalamic-pituitary-adrenocortical axis and the hypothalamic-pituitary-gonadal axis (Lawrence \& Kim 2000). Although such stress responses are essential to survival, inadequate, excessive or unremitting adrenocortical and autonomic function is detrimental for reproduction and survival and can have dramatic effects on immunocompetence (Leonard 2006), thereby increasing susceptibility and vulnerability to disease (Friedman \& Lawrence 2002).

There are a number of mechanisms that animals use to counteract or mitigate negative effects of stress responses, such as seasonal modulation of responses (Romero 2002), acclimatization (French et al. 2008) and reduction in HPA activity (Cyr et al. 2007). These mechanisms should, in principle, allow individuals to survive, despite environmental changes. However, it is possible that co-occurring or unpredictable stressors may exceed those mechanisms (Romero 2002). The consequences of facing and dealing with unpredictable stressors arising from erratic environments may pose additional pressures on the optimal functioning of the immune system and ultimately harm the health and survival of wild populations (Martin 2009).

To fully understand the impacts of anthropogenic environmental change on wildlife health, potential immunosuppressive effects of chronic and unpredictable stressors must be taken into account. Environmental changes have led to the emergence of over 40 infectious diseases since 1970, such as HIV/ AIDS, Ebola and other viral haemorrhagic diseases, new strains of cholera, ranavirus and chytrodiomycosis in amphibians and antibiotic-resistant tuberculosis, and this trend is predicted to increase in the future (Aguirre \& Tabor 2008; Jones et al. 2008; Smith et al. 2009). Such a trend implies that an optimal immune system will be essential to ensure the viability and persistence of individuals and populations.

\section{(a) Stress-induced immunosuppression}

During periods of sustained stress, circulating levels of glucocorticoids are known to increase owing to activation of the hypothalamic-pituitary-adrenocortical axis (Shanks et al. 1994). These adrenal hormones have powerful anti-inflammatory and immunosuppressive properties that can modulate all steps of the 
immune response, including the maturation, selection and proliferation of lymphocytes and the activation of inflammatory cells (Griffin 1989). Glucocorticoids also inhibit the production of various cytokines (e.g. IL (Interleukin)-1, IL-6 and TNF (Tumoral Necrosis Factor)- $\alpha$ ) (Tait et al. 2008) and promote downregulation of lymphocyte function, particularly of pro-inflammatory and cellular responses (Elenkov 2004).

Various studies have measured circulating levels of glucocorticoids in a number of wildlife species, although few have examined the effects that the released stress hormones can exert on immune parameters (Berger et al. 2005). These studies have shown that glucocorticoid levels can increase significantly due to various stressors, including human disturbances (e.g. Arlettaz et al. 2007; Schmidt et al. 2009), increased predator presence (e.g. Polednik et al. 2008) and climate fluctuations (e.g. Hangalapura et al. 2003; Romero et al. 2006; Shultz \& Kitaysky 2008). Nonetheless, a few studies have failed to find an association between glucocorticoid levels and human proximity (e.g. von der Ohe et al. 2004). In one case, it was found that animals (lizards) from urban sites had lower baseline and stress-induced corticosterone blood levels than those from rural areas, suggestive of adaptive mechanisms for counteracting stress responses (French et al. 2008). These conflicting results highlight the difficulty of making generalizations concerning the role of environmental change and stress responses. They also underscore the need for further studies to increase our comprehension of potential additive effects and of the relative importance of long term and concurrent stressors on immunocompetence, health and survival of wild populations.

\section{(b) Pollutant-induced immunosuppression}

Assessing the health risk posed by environmental change is further complicated because, in addition to potential alterations caused by overwhelmed responses to unpredictable stressors, immune responses may also be affected directly by anthropogenic drivers of change, such as the pollutants that have greatly accumulated in both terrestrial and aquatic ecosystems in the last several decades (Boon et al. 2002; Fairbrother et al. 2004; Noyes et al. 2009) and are currently considered a threat to a large number of species (Schipper et al. 2008).

Even taking into account the difficulty of determining lethal exposure levels for wildlife and elucidating the variations in species' sensitivities to different contaminants (Raimondo et al. 2007), there is growing evidence that common environmental pollutants, such as organochlorines and heavy metals, may impair immunocompetence and health in a wide range of animal taxa (Selgrade 2007). This effect will potentially increase susceptibility to infectious and non-infectious disease. Polychlorinated biphenyls (PCBs) are one of the contaminants that have received much attention owing to their immunotoxic effects (Fisk et al. 2005). Moreover, PCBs and other pollutants (mainly aromatic and hydrophobic compounds) can cause DNA strand breakage or bind covalently to nucleotides (i.e. adduct formation) (Luch 2005). While such genotoxic effects remain mostly unexplored for most wildlife taxa, studies in laboratory animals have shown that unrepaired DNA damage can lead to gamete loss, lethal embryonic mutations, abnormal development and cancer (Hinton et al. 2005) and it is likely that exposed wildlife will face similar consequences.

Among other higher vertebrates, marine mammals appear to be particularly susceptible to persistent pollutants, mainly owing to their trophic position, large adipose reserves and long life spans (Aguilar et al. 1999). For example, high PCB concentrations in harbour porpoises have been related to elevated nematode burdens (Bull et al. 2006), impaired health (Jepson et al. 2005) and infectious disease outbreaks (Hall et al. 2006). Moreover, there is evidence from belugas from heavily polluted areas (Martineau et al. 1988) that exposure to persistent contaminants can also induce detectable DNA damage and increase the risk of developing cancer (Martineau et al. 1994).

Associations between anthropogenic pollutants and immunocompetence have also been reported for amphibians and birds, where exposure to heavy metals, pesticides (e.g. DDT and malathion) and herbicides has been correlated with poor immune responses (Gilbertson et al. 2003; Snoeijs et al. 2005; Koprivnikar et al. 2007), viral, fungal and helminth infections (Forson \& Storfer 2006; Davidson et al. 2007; Rohr et al. 2008) and mortality events (Daszak et al. 1999). Amphibians appear to be particularly sensitive to the effects of anthropogenic pollutants (Hopkins 2007), probably owing to their intimate association with the aquatic environment during key life-stages (i.e. larval development and breeding) and their permeable skin (Pessier 2002). For amphibians, the population-level consequences of exposure to agrochemicals extend beyond immunosuppression and disease risk, because these pollutants can also alter reproductive parameters and hamper development. For instance, the widely used agrochemical atrazine has not only been found to reduce white blood cell counts and phagocytic activity of the northern leopard frog, Lithobates (formerly Rana) pipiens (Brodkin et al. 2007), but can also alter sex ratios and reduce the testicular content of spermatids (Orton et al. 2006). Furthermore, limb deformities and infections caused by parasitic infectious diseases have increasingly been associated with agrochemicals (Johnson et al. 2007). Taken together, these observations strongly suggest that agrochemicals are likely to impact health and reproductive success of exposed populations, particularly when in conjunction with other environmental stressors.

\section{ANTHROPOGENIC DRIVERS OF WILDLIFE DISEASE}

Identifying the cause of wildlife diseases is difficult because rarely can a single factor be identified as responsible, a concept commonly termed the 'epidemiological triad' (figure 1). In addition to immune suppression related to exceeded stress responses and pollutant exposure, environmental change can 


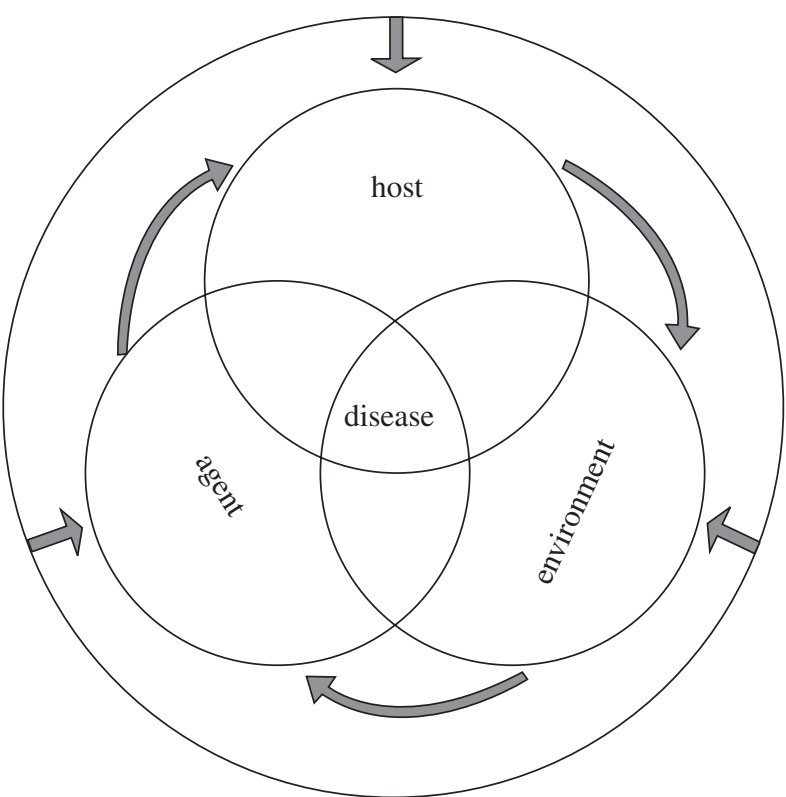

Figure 1. Epidemiological triad. Occurrence of disease results from the interaction between host, environment and disease-agent components (e.g. pathogen or a chemical, UV radiation). Critical host components might be age, sex, genetic background, nutritional and physiological status or prior immune exposure to a pathogen. Environmental host components include climate, interaction with other species, densities and aggregation indexes. Each of the three components can alter the others (e.g. a particular climate regime may decrease food availability, thus changing the nutritional status of an individual or may allow a pathogen to be established in a new area or host). In the context of a rapidly changing environment (black circle), all three components will be subject to changes which will, in turn, alter the epidemiological triad.

impinge directly on wildlife health and survival and, consequently, affect the viability of their populations in various intricate ways (figure 2 ). For example, climate-related shifts in pathogen and host ranges and pathogen spillover from humans and domestic animals can both increase exposure to new diseases (reviewed in Smith et al. 2009). Similarly, changes in habitat size or quality might lead to a reduction in prey population sizes and increased competition for resources (Ryall \& Fahrig 2006), which in turn might augment starvation and lead to disease and/or death. Effects will be further complicated if the genetic makeup of the affected populations has been compromised owing to reduced gene flow or inbreeding, as low levels of genetic diversity tend to be correlated with reduced fitness and lowered evolutionary potential (Spielman et al. 2004). Furthermore, some environmental stressors can directly compromise health by inducing genotoxicity, developmental abnormalities or systemic alterations. In this section, we present three cases of known and potential health problems caused by interacting factors related to anthropogenic environmental change.

\section{(a) Climate change, droughts, starvation and disease}

Climate change has altered physical and biological components of the environment, causing shifts in temperature ranges and rainfall indexes and altering the abundance and distribution of predator and prey species, as well as of pathogens and hosts (MacLeod et al. 2007; Tibbetts 2007; Patz et al. 2008). Droughts and scarcity of food associated with climate change are regular occurrences and are expected to become more frequent, particularly in arid and semi-arid ecosystems (Easterling et al. 2000).

Threatened or vulnerable large mammal populations that inhabit such critical ecosystems are likely to be severely affected by these climatic changes. For instance, an extended period of severe drought in Tanzania was related to unusually high mortality of young elephants, particularly of males (Foley et al. 2008). During these extreme climatic events, poor nutrition (i.e. suboptimal levels of protein, vitamins and other essential nutrients) and dehydration will lead to depletion of fat reserves, poor body condition (Beldomenico et al. 2008) and may decrease innate and acquired immune responses. This will reduce resistance to infection, which in turn can impair nutrient absorption owing to altered gut permeability and inflammation, leading to aggravation of the nutritional status (Katona \& Katona-Apte 2008) and further decreasing the chances of survival (Matthews et al. 2006; Beldomenico et al. 2008). A classic example of this positive feedback system is seen in humans, in which malnutrition is the primary cause of immunodeficiency worldwide and which in turn is strongly related to the prevalence of infectious diseases and infant mortality (Katona \& Katona-Apte 2008). For wildlife, such events could have disastrous consequences for already depleted populations.

Meeting the energetic demands placed by nutritional or hydric stress in order to survive is likely to impact upon the demands of other physiological processes, such as immunity, growth, maintenance and reproduction (Houston et al. 2007), even though this resource allocation might result in decreased population fitness. Under this assumption, animals faced with nutritional or hydric stress will 'take the risk' of investing less in reproduction or in maintaining optimal immune responses because in that situation it is more important to reduce the immediate risk of death from starvation, malnutrition or dehydration. This has important implications for the health of wildlife, as a population impacted by poor nutrition or drought will be at a higher risk of acquiring endemic or novel infections.

\section{(b) Urogenital cancer: a complex disease of California sea lions}

Until recently, the reported occurrence of cancer in wildlife has been rare. Although it is likely that the malignant tumours reported for wildlife only account for a fraction of the real cases, the striking difference in incidence rates $(4.5 \%$ or less in captive and freeranging wildlife compared with $30 \%$ or less in humans; Nagy et al. 2007) suggests that cancer is not normally a significant health problem for wildlife. However, exceptions to this have become apparent: since the mid-1990s, an unusually high prevalence (18\% of all animals examined; Lipscomb et al. 2000) 

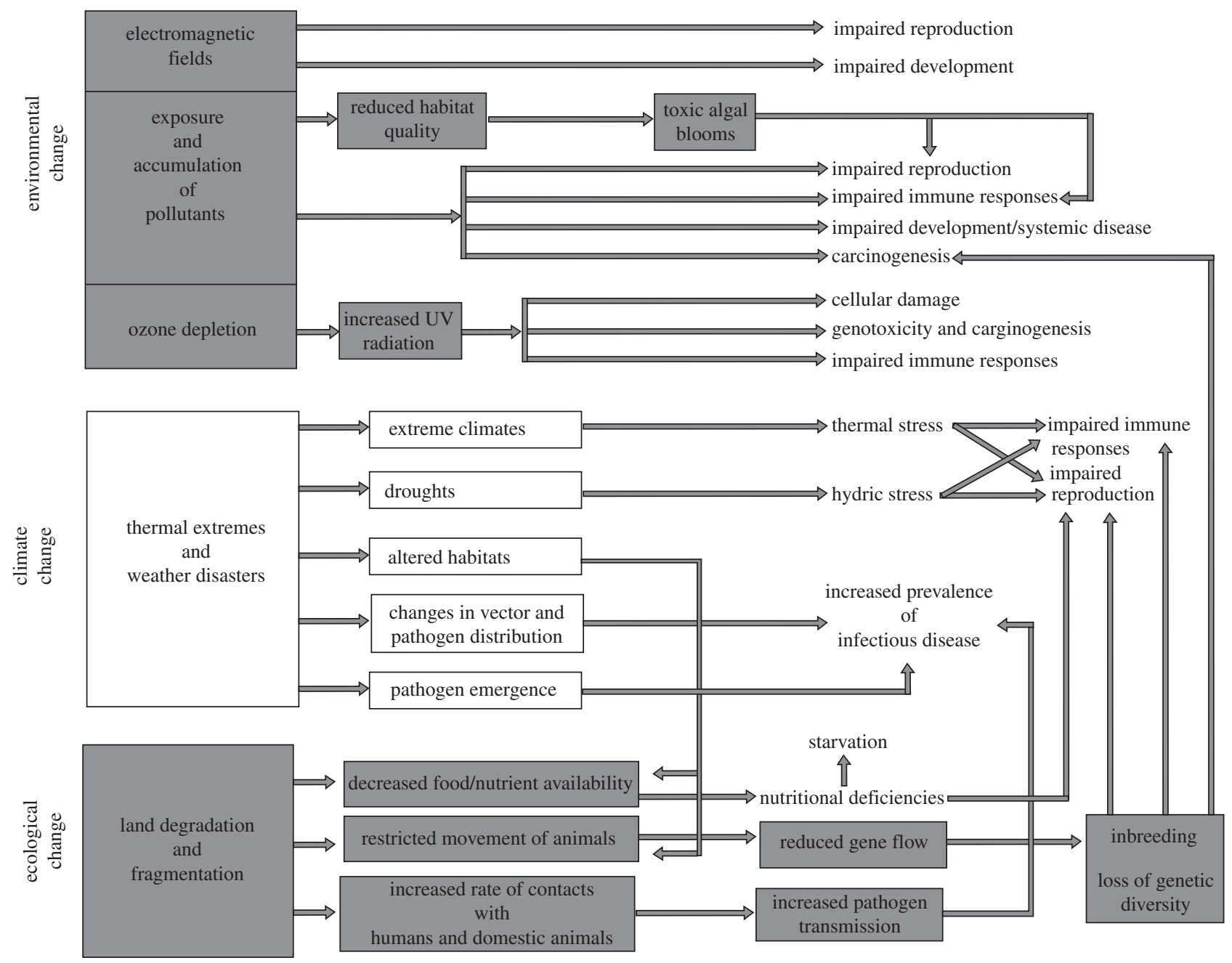

Figure 2. Potential effects of anthropogenic environmental change on wildlife health. The illustration intends to depict the intricate and multiple ways by which changes to the environment can affect health. Regardless of the level at which the changes occur (environmental, climatic and ecological), these will in turn alter other physical and biological processes, eventually increasing the risk of starvation, and exposure to diseases. At an individual level, environmental changes will affect health by weakening immune responses, impairing development and causing systemic disease or cancer.

of epithelial-cell carcinomas of urogenital origin have been observed in adult California sea lions, Zalophus californianus stranded along the central California coast (Gulland et al. 1996; Buckles et al. 2006).

The cause of the problem remains unclear although recent studies have shown that various factors are involved with occurrence of this type of cancer in sea lions, including infection with a novel ottarine gammaherpesvirus (Buckles et al. 2006), high organochlorine concentrations (Ylitalo et al. 2005) and endogenous sex hormones (Colegrove et al. 2009). Genetic factors also seem to play a role in the disease, with high levels of inbreeding (Acevedo-Whitehouse et al. 2003) and specific MHC alleles found to be associated with an increased risk for cancer (Bowen et al. 2005).

The California sea lion is not an endangered species and, regardless of its clinical severity, it is unlikely that urogenital cancer will cause a significant health problem at a population level, particularly since the disease affects mostly sexually mature adults (Gulland et al. 1996; Lipscomb et al. 2000). However, the emergence of this condition is an excellent example of the intricate ways in which anthropogenic environmental change can impact upon wildlife health.

\section{(c) UV radiation and health}

In the past decades, there has been an increase in the amount of harmful UV radiation that reaches the biosphere. This increase has been caused by the reduction in the stratospheric ozone layer which protects the planet from UV radiation. UV radiation is known to cause DNA, cellular and structural damage, which can lead to skin cancer (Situm et al. 2008) and can also impair cell-mediated immune responses (Marrot \& Meunier 2008). In contrast to the many studies conducted in humans (reviewed in Marrot \& Meunier 2008) and marine invertebrates (e.g. Hader et al. 2007; Pruski et al. 2009), there have been strikingly few efforts to investigate the effects of UV exposure in wildlife, and thus, increased UV radiation is rarely taken into consideration when assessing the health of a species or population.

One notable exception to this paucity of studies is the research conducted in amphibians. Several empirical and experimental studies have shown that UV radiation can be detrimental to amphibian development (Hakkinen et al. 2001; Ankley et al. 2002), hatching success (Blaustein et al. 1997), susceptibility to infection (e.g. Kiesecker \& Blaustein 1995; 
Kiesecker et al. 2001, but see Garcia et al. 2006) and survival (Formicki et al. 2008). The magnitude of the effect appears to vary between life stages (being stronger for developing individuals; Ankley et al. 2002) and between species. For instance, while ambient exposure to UV radiation decreases hatching success and survival in Rana arvalis, no effects were detected in $R$. temporaria and Bufo bufo (Hakkinen et al. 2001), raising the possibility that there may be genetic differences in susceptibility and/or avoidance behaviour between species.

The effects of UV radiation on health are particularly relevant for amphibians because various other disruptors (e.g. habitat loss, climate change, disease emergence and eutrophication) are already associated with the current global decline of this taxon (Sodhi et al. 2008; Rovito et al. 2009), and it is likely that this stressor might increase the risk by negatively affecting the health of their populations. Other taxonomic groups living in regions with high exposure to UV radiation (e.g. the Antarctic), at high altitudes or those lacking anatomical or behavioural adaptations to UV exposure (e.g. marine mammals) might also be at risk from UV damaging effects.

\section{THE IMMUNE-REPRODUCTIVE LINK}

In the context of a rapidly changing environment, one further complication for wildlife health arises from the link between the immune and reproductive systems. One of the proposed explanations for this association relates to resource partitioning. Under this hypothesis, maintaining a competent immune system will incur an energetic cost; thus, the resources required to preserve a functional system and to mount specific immune responses may be drawn away from other key physiological processes, such as growth and reproduction (reviewed in Norris \& Evans 2000; Sheldon \& Verhulst 1996). In a high-risk disease scenario, devoting resources for reproduction might decrease future reproductive success through the consequential effects of low investment in immune responses (Gustafsson et al. 1994). If the energetic demands to cover an immune response were not met, the likely consequence would be the occurrence of disease, which might then lead to reduced host performance and increased mortality (Hanssen et al. 2003). The trade-off between key physiological processes works in both directions: during times when energetic demands are high (e.g. during reproduction) immune function may be decreased to allow an individual to maximize its reproductive effort, thereby increasing the likelihood of successful survival of offspring (Norris \& Evans 2000) but also potentially increasing susceptibility to infection.

While the energetic trade-off hypothesis is not without detractors (reviewed in Lochmiller \& Deerenberg 2000), a growing number of experimental studies have shown that increased immune activity diverts resources from traits such as development of sexual ornamentation (e.g. Zuk \& Johnsen 2000), clutch size (e.g. Martin et al. 2001), nestling provisioning (e.g. Ilmonen et al. 2000) and offspring growth rates (e.g. Fair et al. 1999). If we are to generalize from these observations in the context of fast-paced environmental changes that directly and indirectly pose additional pressures on the immune system of wildlife species, it is likely that there will be population-level costs in terms of reproductive parameters and other physiological traits. As yet, this remains to be explored fully.

\section{CONCLUSIONS AND FUTURE DIRECTIONS}

Ecosystems are currently undergoing rapid rates of change, which have the potential to inflict severe damage on the health of wildlife and humans. Repercussions are not only important at an individual level (e.g. cancer and immunosuppression), but can have important population level implications (e.g. reduced reproduction $=$ population decline; reduced immune responses $=$ increased infectious disease). The increasing rates of disease (both infectious and noninfectious) in wildlife is of great concern since disease may be an indication that populations are approaching a state of stress which is negatively affecting immune function, and it is unknown how close this is to the upper limits of their tolerance. When examining the impacts of environmental change on wildlife health, multiple layers of complexity need to be examined and the interactions between different factors need to be considered. Because of the complexity of immune responses, trade-offs between key physiological processes, as well as the potential additive effects of some environmental disruptors on both the immune response and reproductive systems, this wide approach has seldom, if ever, been used to assess potential impacts on population health.

This is an exciting time in terms of research possibilities. The abundant data and laboratory tools developed for studies of both humans and model organisms can be extremely useful to attempt addressing key questions on wildlife health. This approach, in addition to the use of a rigorous and 'environmentally explicit' framework that considers all levels of environmental change will undoubtedly allow researchers to examine the root causes of existing health conditions and potential future diseases for wildlife in the context of a rapidly changing environment.

We thank Frances Orton, Paddy Brock and Laura Martinez for their valuable comments and suggestions on sections of the manuscript. Two anonymous referees provided timely comments that greatly improved our review. K.A.-W.'s research was supported by Morris Animal Foundation, The British Ecological Society and The Royal Society and A.L.J.D. is supported by a Queen Mary, University of London Studentship and a Natural Science and Engineering Council (NSERC) of Canada Doctoral Award.

\section{REFERENCES}

Acevedo-Whitehouse, K., Gulland, F., Greig, D. \& Amos, W. 2003 Inbreeding: disease susceptibility in California sea lions. Nature 422, 35. (doi:10.1038/422035a)

Aguilar, A., Borrell, A. \& Pastor, T. 1999 Biological factors affecting variability of persistent pollutant levels in cetaceans. F Cetacean Res Manage (Special Issue 1), 83-116. 
Aguirre, A. A. \& Tabor, G. M. 2008 Global factors driving emerging infectious diseases. Ann. NY Acad. Sci. 1149, 1-3. (doi:10.1196/annals.1428.052)

Ankley, G. T., Diamond, S. A., Tietge, J. E., Holcombe, G. W., Jensen, K. M., Defoe, D. L. \& Peterson, R. 2002 Assessment of the risk of solar ultraviolet radiation to amphibians. I. Dose-dependent induction of hindlimb malformations in the northern leopard frog (Rana pipiens). Environ. Sci. Technol. 36, 2853-2858. (doi:10.1021/ es011195t)

Arlettaz, R., Patthey, P., Baltic, M., Leu, T., Schaub, M., Palme, R. \& Jenni-Eiermann, S. 2007 Spreading freeriding snow sports represent a novel serious threat for wildlife. Proc. R. Soc. B 274, 1219-1224. (doi:10.1098/ rspb.2006.0434)

Beldomenico, P. M., Telfer, S., Gebert, S., Lukomski, L., Bennett, M. \& Begon, M. 2008 Poor condition and infection: a vicious circle in natural populations. Proc. R. Soc. B 275, 1753-1759. (doi:10.1098/rspb.2008.0147)

Berger, S., Martin II, L. B., Wikelski, M., Romero, L. M., Kalko, E. K. V., Vitousek, M. N. \& Rödl, T. 2005 Corticosterone suppresses immune activity in territorial Galápagos marine iguanas during reproduction. Horm. Behav. 47, 419-429.

Blaustein, A. R., Kiesecker, J. M., Chivers, D. P. \& Anthony, R. G. 1997 Ambient UV-B radiation causes deformities in amphibian embryos. Proc. Natl Acad. Sci. USA 94, $13735-13737$.

Boon, J. P., Lewis, W. E., Tjoen, A. C. M. R., Allchin, C. R., Law, R. J., De Boer, J., Ten Hallers-Tjabbes, C. C. \& Zegers, B. N. 2002 Levels of polybrominated diphenyl ether (PBDE) flame retardants in animals representing different trophic levels of the North Sea food Web. Environ. Sci. Technol. 36, 4025-4032. (doi:10.1021/ es0158298)

Borghesi, L. \& Milcarek, C. 2007 Innate versus adaptive immunity: a paradigm past its prime? Cancer Res. 67, 3989-3993. (doi:10.1158/0008-5472.CAN-07-0182)

Bowen, L., Aldridge, B. M., Delong, R., Melin, S., Buckles, E. L., Gulland, F., Lowenstine, L. J., Stott, J. L. \& Johnson, M. L. 2005 An immunogenetic basis for the high prevalence of urogenital cancer in a free-ranging population of California sea lions (Zalophus californianus). Immunogenetics 56, 846-848. (doi:10.1007/s00251-0040757-z)

Brandau Jr, A. G. \& Gilbert, C. A. 2007 Common variable immunodeficiency: an uncommon disease with high mortality. F. Insur. Med. 39, 71-77.

Brodkin, M. A., Madhoun, H., Rameswaran, M. \& Vatnick, I. 2007 Atrazine is an immune disruptor in adult northern leopard frogs (Rana pipiens). Environ. Toxicol. Chem. 26, 80-84. (doi:10.1897/05-469.1)

Buckles, E. L. et al. 2006 Otarine Herpesvirus-1, not papillomavirus, is associated with endemic tumours in California sea lions (Zalophus californianus). F. Comp. Pathol. 135, 183-189. (doi:10.1016/j.jcpa.2006.06.007)

Bull, J. C., Jepson, P. D., Ssuna, R. K., Deaville, R., Allchin, C. R., Law, R. J. \& Fenton, A. 2006 The relationship between polychlorinated biphenyls in blubber and levels of nematode infestations in harbour porpoises, Phocoena phocoena. Parasitology 132, 565-573. (doi:10.1017/S003118200500942X)

Colegrove, K., Gulland, F., Naydan, D. \& Lowenstine, L. 2009 Tumor morphology and immunohistochemical expression of estrogen receptor, progesterone receptor, p53, and Ki67 index in urogenital carcinomas of California sea lions (Zalophus californianus). Vet. Pathol. 46, 642-655. (doi:10.1354/vp.08-VP-0214-C-FL)

Cyr, N. E., Earle, K., Tam, C. \& Romero, L. M. 2007 The effect of chronic psychological stress on corticosterone, plasma metabolites, and immune responsiveness in European starlings. Gen. Comp. Endocrinol. 154, 59-66. (doi:10.1016/j.ygcen.2007.06.016)

Daszak, P., Berger, L., Cunningham, A. A., Hyatt, A. D., Green, D. E. \& Speare, R. 1999 Emerging infectious diseases and amphibian population declines. Emerg. Infect. Dis. 5, 735-748.

Davidson, C., Benard, M. F., Shaffer, H. B., Parker, J. M., O'Leary, C., Conlon, J. M. \& Rollins-Smith, L. A. 2007 Effects of chytrid and carbaryl exposure on survival, growth and skin peptide defenses in foothill yellow-legged frogs. Environ. Sci. Technol. 41, 1771-1776. (doi:10. 1021/es0611947)

Deem, S. L., Kaersh, W. B. \& Weisman, W. 2001 Putting theory into practice: wildlife health in conservation. Conserv. Biol. 15, 1224-1233. (doi:10.1046/j.1523-1739. 2001.00336.x)

Easterling, D. R., Meehl, G. A., Parmesan, C., Changnon, S. A., Karl, T. R. \& Mearns, L. O. 2000 Climate extremes: observations, modeling, and impacts. Science 289, 2068-2074. (doi:10.1126/science.289. $5487.2068)$

Elenkov, I. J. 2004 Glucocorticoids and the Th1/Th2 balance. Ann. NY Acad. Sci. 1024, 138-146. (doi:10.1196/ annals.1321.010)

Fair, J. M., Hansen, E. S. \& Ricklefs, R. E. 1999 Growth, developmental stability and immune response in juvenile Japanese quails (Coturnix coturnix japonica). Proc. Biol. Sci. 266, 1735-1742. (doi:10.1098/rspb.1999.0840)

Fairbrother, A., Smits, J. \& Grasman, K. 2004 Avian immunotoxicology. F. Toxicol. Environ. Health B Crit. Rev. 7, 105-137.

Fisk, A. T. et al. 2005 An assessment of the toxicological significance of anthropogenic contaminants in Canadian arctic wildlife. Sci. Total Environ. 351-352, 57-93. (doi:10.1016/j.scitotenv.2005.01.051)

Foley, C., Pettorelli, N. \& Foley, L. 2008 Severe drought and calf survival in elephants. Biol. Lett. 4, 541-544. (doi:10. 1098/rsbl.2008.0370)

Formicki, G., Stawarz, R., Lukac, N., Putala, A. \& Kuczkowska, A. 2008 Combined effects of cadmium and ultraviolet radiation on mortality and mineral content in common frog (Rana temporaria) larvae. F. Environ. Sci. Health A Tox. Hazard Subst. Environ. Eng. 43, 1174-1183.

Forson, D. D. \& Storfer, A. 2006 Atrazine increases ranavirus susceptibility in the tiger salamander, Ambystoma tigrinum. Ecol. Appl. 16, 2325-2332. (doi:10.1890/ 1051-0761(2006)016[2325:AIRSIT]2.0.CO;2)

French, S. S., Fokidis, H. B. \& Moore, M. C. 2008 Variation in stress and innate immunity in the tree lizard (Urosaurus ornatus) across an urban-rural gradient. F. Comp. Physiol. $B$ 178, 997-1005.

Friedman, E. M. \& Lawrence, D. A. 2002 Environmental stress mediates changes in neuroimmunological interactions. Toxicol. Sci. 67, 4-10.

Garcia, T. S., Romansic, J. M. \& Blaustein, A. R. 2006 Survival of three species of anuran metamorphs exposed to UV-B radiation and the pathogenic fungus Batrachochytrium dendrobatidis. Dis. Aquat. Organ 72, 163-169. (doi:10.3354/dao072163)

Gilbertson, M. K., Haffner, G. D., Drouillard, K. G., Albert, A. \& Dixon, B. 2003 Immunosuppression in the northern leopard frog (Rana pipiens) induced by pesticide exposure. Environ. Toxicol. Chem. 22, 101-110. (doi:10. 1897/1551-5028(2003)022<0101:IITNLF > 2.0.CO;2)

Griffin, J. F. 1989 Stress and immunity: a unifying concept. Vet. Immunol. Immunopathol. 20, 263-312. (doi:10.1016/ 0165-2427(89)90005-6)

Gulland, F. M., Trupkiewicz, J. G., Spraker, T. R. \& Lowenstine, L. J. 1996 Metastatic carcinoma of probable 
transitional cell origin in 66 free-living California sea lions (Zalophus californianus), 1979 to 1994. F. Wildl. Dis. 32, $250-258$.

Gustafsson, L., Nordling, D., Andersson, M. S., Sheldon, B. C. \& Qvarnstrom, A. 1994 Infectious diseases, reproductive effort and the cost of reproduction in birds. Phil. Trans. R. Soc. Lond. B 346, 323-331. (doi:10.1098/rstb.1994.0149)

Hader, D. P., Kumar, H. D., Smith, R. C. \& Worrest, R. C. 2007 Effects of solar UV radiation on aquatic ecosystems and interactions with climate change. Photochem. Photobiol. Sci. 6, 267-285.

Hakkinen, J., Pasanen, S. \& Kukkonen, J. V. 2001 The effects of solar UV-B radiation on embryonic mortality and development in three boreal anurans (Rana temporaria, Rana arvalis and Bufo bufo). Chemosphere 44, 441-446. (doi:10.1016/S0045-6535(00)00295-2)

Hall, A. J., Hugunin, K., Deaville, R., Law, R. J., Allchin, C. R. \& Jepson, P. D. 2006 The risk of infection from polychlorinated biphenyl exposure in the harbor porpoise (Phocoena phocoena): a case-control approach. Environ. Health Perspect. 114, 704-711.

Hangalapura, B. N., Nieuwland, M. G., de Vries Reilingh, G., Heetkamp, M. J., van den Brand, H., Kemp, B. \& Parmentier, H. K. 2003 Effects of cold stress on immune responses and body weight of chicken lines divergently selected for antibody responses to sheep red blood cells. Poult. Sci. 82, 1692-1700.

Hanssen, S. A., Folstad, I. \& Erikstad, K. E. 2003 Reduced immunocompetence and cost of reproduction in common eiders. Oecologia 136, 457-464. (doi:10.1007/s00442003-1282-8)

Haussmann, M. F., Winkler, D. W., Huntington, C. E., Vleck, D., Sanneman, C. E., Hanley, D. \& Vleck, C. M. 2005 Cell-mediated immunosenescence in birds. Oecologia $145,270-275$.

Havens, K. E. 2008 Cyanobacteria blooms: effects on aquatic ecosystems. Adv. Exp. Med. Biol. 619, 733-747. (doi:10.1007/978-0-387-75865-7_33)

Hinton, D. E., Kullman, S. W., Hardman, R. C., Volz, D. C., Chen, P. J., Carney, M. \& Bencic, D. C. 2005 Resolving mechanisms of toxicity while pursuing ecotoxicological relevance? Mar. Pollut. Bull. 51, 635-648. (doi:10.1016/ j.marpolbul.2005.07.020)

Hoffmann, A. A. \& Willi, Y. 2008 Detecting genetic responses to environmental change. Nat. Rev. Genet. 9, 421-432. (doi: 10.1038/nrg2339)

Hopkins, W. A. 2007 Amphibians as models for studying environmental change. ILAR f. 48, 270-277.

Houston, A. I., McNamara, J. M., Barta, Z. \& Klasing, K. C. 2007 The effect of energy reserves and food availability on optimal immune defence. Proc. R. Soc. B 274, 2835-2842. (doi:10.1098/rspb.2007.0934)

Hughes, T. P. et al. 2003 Climate change, human impacts, and the resilience of coral reefs. Science 301, 929-933. (doi:10.1126/science.1085046)

Husband, A. J. \& Bryden, W. L. 1996 Nutrition, stress and immune activation. Proc. Nutr. Soc. Austr. 20, 60-70.

Ilmonen, P., Taarna, T. \& Hasselquist, D. 2000 Experimentally activated immune defence in female pied flycatchers results in reduced breeding success. Proc. R. Soc. B 267, 665-670. (doi:10.1098/rspb.2000.1053)

Jackson, J. B. et al. 2001 Historical overfishing and the recent collapse of coastal ecosystems. Science 293, 629-637. (doi:10.1126/science.1059199)

Jepson, P. D., Bennett, P. M., Deaville, R., Allchin, C. R., Baker, J. R. \& Law, R. J. 2005 Relationships between polychlorinated biphenyls and health status in harbor porpoises (Phocoena phocoena) stranded in the United Kingdom. Environ. Toxicol. Chem. 24, 238-248. (doi:10. 1897/03-663.1)
Johnson, P. T., Chase, J. M., Dosch, K. L., Hartson, R. B., Gross, J. A., Larson, D. J., Sutherland, D. R. \& Carpenter, S. R. 2007 Aquatic eutrophication promotes pathogenic infection in amphibians. Proc. Natl Acad. Sci. USA 104, 15781-15786. (doi:10.1073/pnas. 0707763104)

Jones, K. E., Patel, N. G., Levy, M. A., Storeygard, A., Balk, D., Gittleman, J. L. \& Daszak, P. 2008 Global trends in emerging infectious diseases. Nature 451, 990-993. (doi:10.1038/nature06536)

Katona, P. \& Katona-Apte, J. 2008 The interaction between nutrition and infection. Clin. Infect. Dis. 46, 1582-1588. (doi:10.1086/587658)

Kiesecker, J. M. \& Blaustein, A. R. 1995 Synergism between UV-B radiation and a pathogen magnifies amphibian embryo mortality in nature. Proc. Natl Acad. Sci. USA 92, 11049-11052. (doi:10.1073/pnas.92.24.11049)

Kiesecker, J. M., Blaustein, A. R. \& Belden, L. K. 2001 Complex causes of amphibian population declines. Nature 410, 681-684. (doi:10.1038/35070552)

Koprivnikar, J., Forbes, M. R. \& Baker, R. L. 2007 Contaminant effects on host-parasite interactions: atrazine, frogs, and trematodes. Environ. Toxicol. Chem. 26, 2166-2170. (doi:10.1897/07-220.1)

Kvell, K., Cooper, E. L., Engelmann, P., Bovari, J. \& Nemeth, P. 2007 Blurring borders: innate immunity with adaptive features. Clin. Dev. Immunol. 2007, 83671.

Lawrence, D. A. \& Kim, D. 2000 Central/peripheral nervous system and immune responses. Toxicology 142, 189-201. (doi:10.1016/S0300-483X(99)00144-4)

Leonard, B. E. 2006 HPA and immune axes in stress: involvement of the serotonergic system. Neuroimmunomodulation 13, 268-276. (doi:10.1159/ $000104854)$

Lipscomb, T. P., Scott, D. P., Garber, R. L., Krafft, A. E., Tsai, M. M., Lichy, J. H., Taubenberger, J. K., Schulman, F. Y. \& Gulland, F. M. 2000 Common metastatic carcinoma of California sea lions (Zalophus californianus): evidence of genital origin and association with novel gammaherpesvirus. Vet. Pathol. 37, 609-617. (doi:10.1354/vp.37-6-609)

Lochmiller, R. L. 1996 Immuno-competence and animal population regulation. Oikos 76, 594-602. (doi:10. 2307/3546356)

Lochmiller, R. L. \& Deerenberg, C. 2000 Trade-offs in evolutionary immunology: just what is the cost of immunity? Oikos 88, 87-98. (doi:10.1034/j.1600-0706.2000.880110.x)

Luch, A. 2005 Nature and nurture-lessons from chemical carcinogenesis. Nat. Rev. Cancer 5, 113-125. (doi:10. 1038/nrc1546)

MacLeod, C. D., Santos, M. B., Reid, R. J., Scott, B. E. \& Pierce, G. J. 2007 Linking sandeel consumption and the likelihood of starvation in harbour porpoises in the Scottish North Sea: could climate change mean more starving porpoises? Biol. Lett. 3, 185-188. (doi:10.1098/rsbl. 2006.0588)

Marrot, L. \& Meunier, J. R. 2008 Skin DNA photodamage and its biological consequences. F. Am. Acad. Dermatol. 58, S139-S148. (doi:10.1016/j.jaad.2007.12.007)

Martin, L. B. 2009 Stress and immunity in wild vertebrates: timing is everything. Gen. Comp. Endocrinol. 163, 70-76.

Martin, T. E., Moller, A. P., Merino, S. \& Clobert, J. 2001 Does clutch size evolve in response to parasites and immunocompetence? Proc. Natl Acad. Sci. USA 98, 2071-2076. (doi:10.1073/pnas.98.4.2071)

Martineau, D., Lagace, A., Beland, P., Higgins, R., Armstrong, D. \& Shugart, L. R. 1988 Pathology of stranded beluga whales (Delphinapterus leucas) from the St. Lawrence Estuary, Quebec, Canada. F. Comp. Pathol. 98, 287-311. (doi:10.1016/0021-9975(88)90038-2) 
Martineau, D., De Guise, S., Fournier, M., Shugart, L., Girard, C., Lagace, A. \& Beland, P. 1994 Pathology and toxicology of beluga whales from the St. Lawrence Estuary, Quebec, Canada. Past, present and future. Sci. Total Environ. 154, 201-215.

Matthews, R. J., Jagger, C. \& Hancock, R. M. 2006 Does socio-economic advantage lead to a longer, healthier old age? Soc. Sci. Med. 62, 2489-2499. (doi:10.1016/j.socscimed.2005.11.019)

Moller, A. P. \& Saino, N. 2004 Immune response and survival. Oikos 104, 299-304. (doi:10.1111/j.0030-1299. 2004.12844.x)

Nagy, J. D., Victor, E. M. \& Cropper, J. H. 2007 Why don't all whales have cancer? A novel hypothesis resolving Peto's paradox. Integr. Comp. Biol. 2007, 1-12.

Nizet, V. 2006 Antimicrobial peptide resistance mechanisms of human bacterial pathogens. Curr. Issues Mol. Biol. 8, $11-26$.

Norlin, A. C., Sairafi, D., Mattsson, J., Ljungman, P., Ringden, O. \& Remberger, M. 2008 Allogeneic stem cell transplantation: low immunoglobulin levels associated with decreased survival. Bone Marrow Transplant. 41, 267-273. (doi:10.1038/sj.bmt.1705892)

Norris, K. \& Evans, M. R. 2000 Ecological immunology: life history trade-offs and immune defense in birds. Behav. Ecol. 11, 19-26. (doi:10.1093/beheco/11.1.19)

Noyes, P. D., McElwee, M. K., Miller, H. D., Clark, B. W., Van Tiem, L. A., Walcott, K. C., Erwin, K. N. \& Levin, E. D. 2009 The toxicology of climate change: Environmental contaminants in a warming world. Environ. Int. 35, 971-986.

Orton, F., Carr, J. A. \& Handy, R. D. 2006 Effects of nitrate and atrazine on larval development and sexual differentiation in the northern leopard frog Rana pipiens. Environ. Toxicol. Chem. 25, 65-71. (doi:10.1897/05-136R.1)

Patz, J. A., Olson, S. H., Uejio, C. K. \& Gibbs, H. K. 2008 Disease emergence from global climate and land use change. Med. Clin. North Am. 92, 1473-1491. xii. (doi:10.1016/j.mcna.2008.07.007)

Paul, V. J. 2008 Global warming and cyanobacterial harmful algal blooms. Adv. Exp. Med. Biol. 619, 239-257. (doi:10.1007/978-0-387-75865-7_11)

Pessier, A. P. 2002 An overview of amphibian skin disease. Semin. Avian Exotic Pet Med. 11, 162-174. (doi:10. 1053/saep.2002.123980)

Polednik, L., Rehulka, J., Kranz, A., Polednikova, K., Hlavac, V. \& Kazihnitkova, H. 2008 Physiological responses of over-wintering common carp (Cyprinus carpio) to disturbance by Eurasian otter (Lutra lutra). Fish Physiol. Biochem. 34, 223-234. (doi:10.1007/ s10695-007-9180-3)

Pruski, A. M., Nahon, S., Escande, M. L. \& Charles, F. 2009 Ultraviolet radiation induces structural and chromatin damage in Mediterranean sea-urchin spermatozoa. Mutat. Res. 673, 67-73.

Raimondo, S., Mineau, P. \& Barron, M. G. 2007 Estimation of chemical toxicity to wildlife species using interspecies correlation models. Environ. Sci. Technol. 41, 5888-5894. (doi:10.1021/es070359o)

Reusch, T. B. \& Wood, T. E. 2007 Molecular ecology of global change. Mol. Ecol. 16, 3973-3992. (doi:10.1111/ j.1365-294X.2007.03454.x)

Rohr, J. R. et al. 2008 Agrochemicals increase trematode infections in a declining amphibian species. Nature 455, 1235-1239. (doi:10.1038/nature07281)

Romero, L. M. 2002 Seasonal changes in plasma glucocorticoid concentrations in free-living vertebrates. Gen. Comp. Endocrinol. 128, 1-24.

Romero, L. M., Cyr, N. E. \& Romero, R. C. 2006 Corticosterone responses change seasonally in free-living house sparrows (Passer domesticus). Gen. Comp. Endocrinol. 149, $58-65$.

Rovito, S. M., Parra-Olea, G., Vasquez-Almazan, C. R., Papenfuss, T. J. \& Wake, D. B. 2009 Dramatic declines in neotropical salamander populations are an important part of the global amphibian crisis. Proc. Natl Acad. Sci. USA. (doi:10.1073/pnas.0813051106)

Ryall, K. L. \& Fahrig, L. 2006 Response of predators to loss and fragmentation of prey habitat: a review of theory. Ecology 87, 1086-1093. (doi:10.1890/0012-9658(2006) 87[1086:ROPTLA]2.0.CO;2)

Schipper, J. et al. 2008 The status of the world's land and marine mammals: diversity, threat, and knowledge. Science 322, 225-230. (doi:10.1126/science.1165115)

Schmidt, K. L., Chin, E. H., Shah, A. H. \& Soma, K. K. 2009 Cortisol and corticosterone in immune organs and brain of European starlings: developmental changes, effects of restraint stress, comparison with zebra finches. Am. F. Physiol. Regul. Integr. Comp. Physiol. 297, R42-R51.

Selgrade, M. K. 2007 Immunotoxicity: the risk is real. Toxicol. Sci. 100, 328-332. (doi:10.1093/toxsci/kfm244)

Shanks, N., Griffiths, J. \& Anisman, H. 1994 Central catecholamine alterations induced by stressor exposure: analyses in recombinant inbred strains of mice. Behav. Brain Res. 63, 25-33. (doi:10.1016/0166-4328(94) 90047-7)

Sheldon, B. C. \& Verhulst, S. 1996 Ecological immunology: costly parasite defenses and trade-offs in evolutionary ecology. Trends Ecol. Evol. 11, 317-321. (doi:10.1016/ 0169-5347(96)10039-2)

Shultz, M. T. \& Kitaysky, A. S. 2008 Spatial and temporal dynamics of corticosterone and corticosterone binding globulin are driven by environmental heterogeneity. Gen. Comp. Endocrinol. 155, 717-728. (doi:10.1016/j. ygcen.2007.11.002)

Situm, M., Buljan, M., Bulat, V., Lugovic Mihic, L., Bolanca, Z. \& Simic, D. 2008 The role of UV radiation in the development of basal cell carcinoma. Coll. Antropol. 32(Suppl. 2), 167-170.

Smith, V. H. 2003 Eutrophication of freshwater and coastal marine ecosystems: a global problem. Environ. Sci. Pollut. Res. Int. 10, 126-139. (doi:10.1065/espr2002.12.142)

Smith, K. F., Acevedo-Whitehouse, K. \& Pedersen, A. B. 2009 The role of infectious diseases on biodiversity. Anim. Conserv. 21, 1-12.

Snoeijs, T., Dauwe, T., Pinxten, R., Darras, V. M., Arckens, L. \& Eens, M. 2005 The combined effect of lead exposure and high or low dietary calcium on health and immunocompetence in the zebra finch (Taeniopygia guttata). Environ. Pollut. 134, 123-132. (doi:10.1016/j.envpol.2004.07.009)

Sodhi, N. S., Bickford, D., Diesmos, A. C., Lee, T. M., Koh, L. P., Brook, B. W., Sekercioglu, C. H. \& Bradshaw, C. J. 2008 Measuring the meltdown: drivers of global amphibian extinction and decline. PLOS ONE 3, e1636. (doi:10.1371/journal.pone.0001636)

Sonne, C., Leifsson, P. S., Dietz, R., Born, E. W., Letcher, R. J., Hyldstrup, L., Riget, F. F., Kirkegaard, M. \& Muir, D. C. 2006 Xenoendocrine pollutants may reduce size of sexual organs in East Greenland polar bears (Ursus maritimus). Environ. Sci. Technol. 40, 5668-5674. (doi:10.1021/ es060836n)

Sonne, C., Dietz, R., Born, E. W., Riget, F. F., Leifsson, P. S., Bechshoft, T. O. \& Kirkegaard, M. 2007 Spatial and temporal variation in size of polar bear (Ursus maritimus) sexual organs and its use in pollution and climate change studies. Sci. Total Environ. 387, 237-246.

Spielman, D., Brook, B. W. \& Frankham, R. 2004 Most species are not driven to extinction before genetic 
factors impact them. Proc. Natl Acad. Sci. USA 101, 15 261-15 264. (doi:10.1073/pnas.0403809101)

Tait, A. S., Butts, C. L. \& Sternberg, E. M. 2008 The role of glucocorticoids and progestins in inflammatory, autoimmune, and infectious disease. F. Leukoc. Biol. 84, 924-931. (doi:10.1189/jlb.0208104)

Thomas, C. D. et al. 2004 Extinction risk from climate change. Nature 427, 145-148. (doi:10.1038/nature02121)

Tibbetts, J. 2007 Driven to extremes: health effects of climate change. Environ. Health Perspect. 115, A196-A203.

Tizard, I. R. 2002 Veterinary immunology-an introduction. Philadelphia, PA: W. B. Saunders.

Uba, A. F., Chirdan, L. B., Ardill, W., Ramyil, V. M. \& Kidmas, A. T. 2004 Acquired rectal fistula in human immunodeficiency virus-positive children: a causal or casual relationship? Pediatr. Surg. Int. 20, 898-901. (doi:10.1007/s00383-004-1285-5)

von der Ohe, C. G., Wasser, S. K., Hunt, K. E. \& Servheen, C. 2004 Factors associated with fecal glucocorticoids in Alaskan brown bears (Ursus arctos horribilis). Physiol. Biochem. Zool. 77, 313-320. (doi:10.1086/378139)

Ylitalo, G. M. et al. 2005 The role of organochlorines in cancer-associated mortality in California sea lions (Zalophus californianus). Mar. Pollut. Bull. 50, 30-39. (doi:10.1016/j.marpolbul.2004.08.005)

Zuk, M. \& Johnsen, T. 2000 Social environment and immunity in male red jungle fowl. Behav. Ecol. 11, 146-153. (doi:10.1093/beheco/11.2.146) 